\title{
Mammary Hibernoma: A Case Report of a Rare Disease
}

\section{Hibernoma mamário: relato de caso de uma doença rara}

\author{
Eduardo Henrique Cunha Neves Filho ${ }^{1}$ Geórgia de Aguiar Feitosa Lima ${ }^{2}$ Ângelo Roncalli Melo Alves ${ }^{1}$ \\ Valdenrique Macêdo de Sousa ${ }^{2}$ Maria do Perpétuo Socorro Saldanha da Cunha ${ }^{1}$
}

1 Section of Pathology, Instituto do Câncer do Ceará, Fortaleza, CE, Brazil

${ }^{2}$ Section of Mastology, Instituto do Câncer do Ceará, Fortaleza, CE, Brazil

Address for correspondence Eduardo Henrique Cunha Neves Filho, MD, Instituto do Câncer do Ceará, Rua Papi Junior, 1222, Fortaleza,

Rev Bras Ginecol Obstet 2018;40:232-234. CE, 60430-230, Brazil (e-mail: edu0689@yahoo.com.br).

\begin{abstract}
Keywords

- hibernoma

- breast benign neoplasia

Resumo

Palavras-chave

- hibernoma

- neoplasia mamária benigna

Mammary hibernomas are extremely rare benign tumors composed of brown fat cells, with only five cases previously reported in the literature. We report the case of a 42year-old female patient with a painless growing mass in her right breast. A partial mastectomy was performed, and the diagnosis of hibernoma was confirmed by the histological features and the immunohistochemical profile. Although hibernoma is a benign tumor, its main differential diagnoses include aggressive lesions, making the accurate diagnosis essential to provide adequate care to the patient.

Hibernomas mamários são tumores benignos extremamente raros compostos por gordura marrom, com apenas cinco casos previamente relatados na literatura. Relatamos o caso de uma paciente do sexo feminino, de 42 anos de idade, apresentando-se com uma massa indolor em sua mama direita. Realizou-se uma mastectomia parcial e o diagnóstico de hibernoma mamário foi confirmado pelo padrão morfológico e pelo perfil imuno-histoquímico. Embora hibernomas constituam neoplasias benignas, seus principais diagnósticos diferenciais incluem lesões agressivas, sendo o diagnóstico acurado extremamente importante para o correto manejo clínico do paciente.
\end{abstract}

\section{Introduction}

Hibernomas are rare benign neoplasms composed of brown fat cells. ${ }^{1}$ These tumors arise from remnants of fetal brown fat, which commonly tends to involve by the first weeks after birth and be replaced by white adipocytes. ${ }^{2}$ Histologically, this kind of adipose tissue is very similar to the one found in hibernating animals, thus the term hibernoma. ${ }^{1}$

Although uncommon, it has been described that hibernomas occur more often in areas where residual brown fat is found, such as the interscapular region, axilla and the groin. ${ }^{3}$ Mammary hibernomas are extremely rare, with only a few cases described in the literature. $^{2-6}$

received

November 23, 2017

accepted

February 7, 2018

published online

March 29, 2018

10.1055/s-0038-1639500. ISSN $0100-7203$.

\section{Case Report}

A 42 years-old female patient presented with a 6 months history of a lump in the upper outer quadrant of her right breast. The lesion was painless, with no association to either edema or papillary discharge. She had her menarche when she was 12, her obstetric history was G1P1A0 and she had been using oral contraception for 6 years. There was no familiar history of breast cancer.

The initial clinical assessment showed a $10.0 \times 10.0 \mathrm{~cm}$ lobulated, well-defined soft mobile mass, with no evidence of axillary or supra/infraclavicular fossae lymphadenopathy. A previous mammography revealed a regular, partially defined

Copyright @ 2018 by Thieme Revinter

Publicações Ltda, Rio de Janeiro, Brazil

License terms

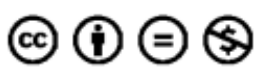




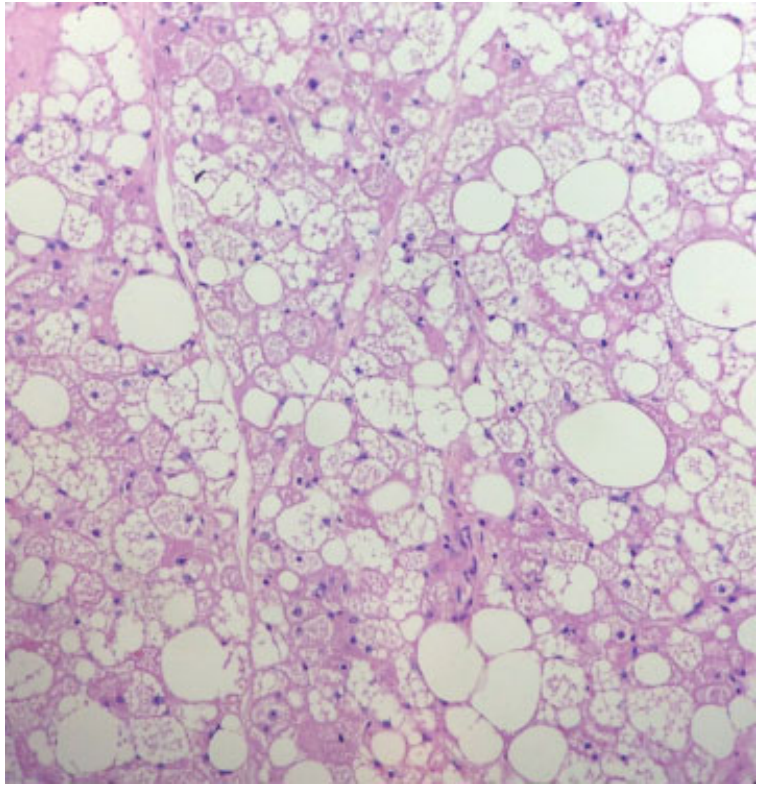

Fig. 1 High power microscopic view (H\&E stain) demonstrating large polygonal cells with abundant multivacuolated, eosinophilic, cytoplasm.

nodule in the upper outer quadrant of her right breast. Additionally, an ultrasound scan of the lesion confirmed a hypoechoic solid nodule of $\sim 10.2 \times 5.0 \mathrm{~cm}$, which occupied most of the upper outer and the upper inner quadrants of the right breast.

The histopathological evaluation of this mass by core biopsy showed fibrous-adipose tissue associated with areas of steatonecrosis, without any evidence of neoplasia in those samples. Therefore, the patient was submitted to partial mastectomy.

The surgical specimen was constituted by a yellowish round mass of $12.0 \times 8.0 \times 4.0 \mathrm{~cm}$, with well-defined boundaries and elastic consistency, showing compact surface after being sectioned. The resection was marginal. Microscopically, the tumor was composed predominantly by lobules of large round to polygonal cells with abundant multivacuolated cytoplasm, well-defined membrane and central nuclei with fine chromatin and prominent nucleoli, which is consistent with a brown fat tumor, admixed with regular white adipocytes and small blood vessels ( - Fig. 1). In addition, the surgical margins were microscopically negative. The diagnosis of mammary hibernoma was confirmed by immunohistochemistry, which revealed positivity for S100 protein; the tumor cells were negative for CD31, CD34, CD68 and topoisomerase (-Fig. 2).

\section{Discussion}

Hibernomas are uncommon benign tumors histologically composed of a specialized form of adipose tissue known as brown fat. ${ }^{2}$ Although the brown adipocytes are gradually replaced by white fat after birth, foci of remnant brown fat may persist in adults; thus, hibernomas might theoretically arise in any area where these foci are found, although a de novo brown fat differentiation is reported as possible. ${ }^{2,5}$ These tumors are mainly being reported in the thigh, shoulder, back, neck, chest, arm, abdominal cavity and retroperitoneum, accounting for only $1.6 \%$ of benign lipomatous neoplasms, with a slight predominance in adult men and a higher incidence between the third and fourth decades of life. ${ }^{5,7}$

Among the mammary benign tumors, hibernomas are one of the rarest with only five cases previously described in the literature. ${ }^{2-6}$ Most cases present with an asymptomatic growing mass, although this tumor might cause symptoms due to adjacent structures compression, or it can be even diagnosed as an incidental finding at a radiological routine examination.

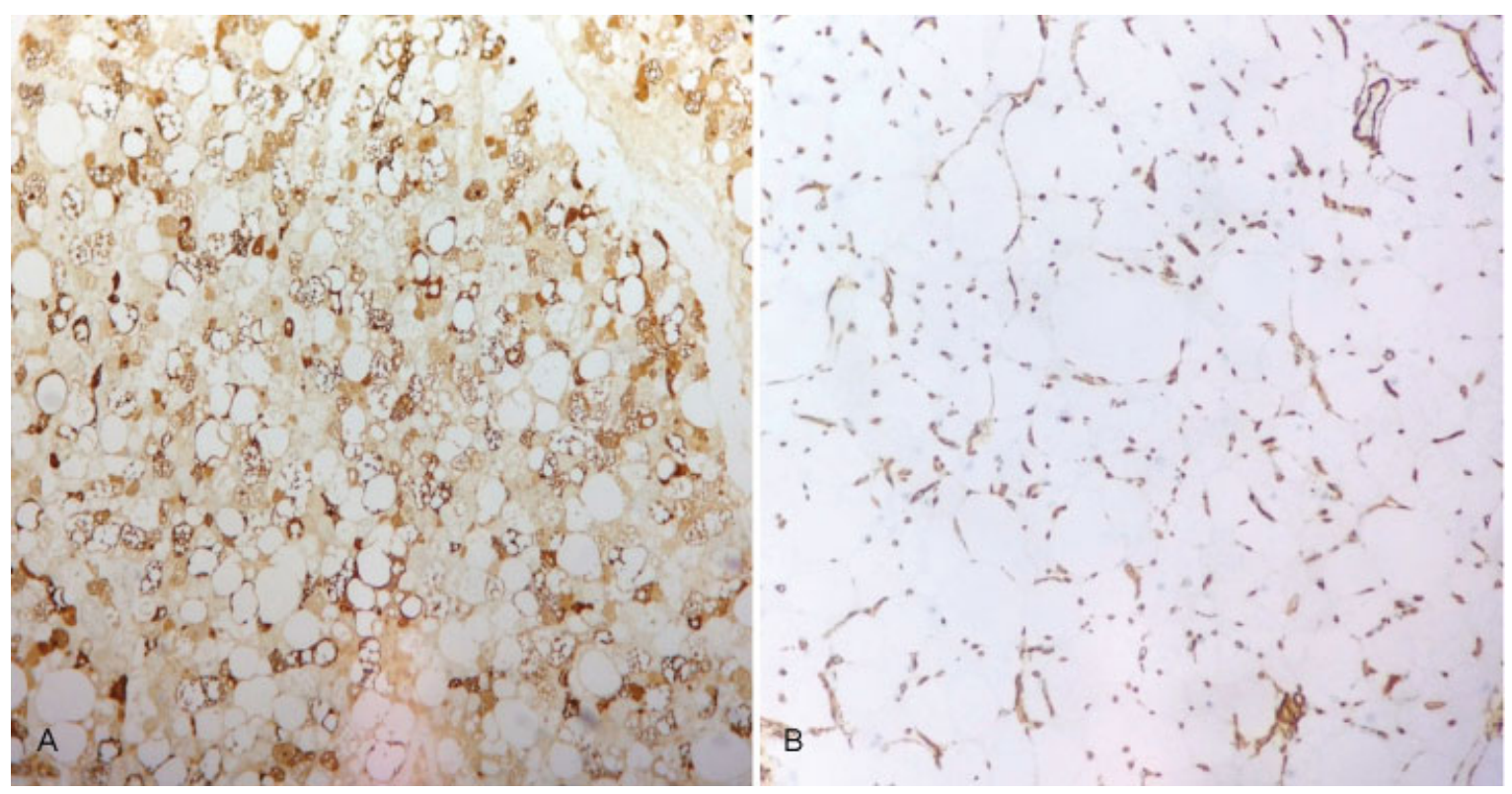

Fig. 2 Microscopic view demonstrating immunohistochemical positivity for S100 (A) and negativity for CD34 (B). 
Grossly, hibernomas are well-circumscribed, lobulated and sometimes partly encapsulated. As sectioned, the cut surface has a yellowish brown hue with a rubbery texture. ${ }^{6}$ On histological examination these tumor exhibit a lobular pattern with pale and eosinophilic multivacuolated fat cells with small, central, or eccentric nuclei admixed with capillaries with a varying degree of differentiation. ${ }^{5,6}$ Nuclear atypia and mitotic figures are exceptionally rare. ${ }^{7}$ The histopathological diagnosis is based upon morphological features. However, although not necessary, immunohistochemistry may be used to confirm adipocyte differentiation. $^{5}$

Corroborating with our findings, immunohistochemical studies of hibernomas show global positivity for S100 protein in both eosinophilic and pale cells with variably intensity and negativity of CD34. ${ }^{5,6}$ Although CD31 was previously reported to might be positive in normal and neoplastic brown fat cells, in our case it was negative. ${ }^{5}$

Differential diagnosis include other lipomatous neoplasms, such as lipoblastoma and well-differentiated liposarcoma, adult rhabdomyoma and fat necrosis. ${ }^{6}$ The likelihood of diagnostic confusion with other tumors with a complete surgical excision is, however, minimal.

The present case was resected with marginal excision. The largest series published to date about hibernomas ( 170 cases derived from the files of the Armed Forces Institute of Pathology - AFIP) revealed no recurrence or aggressive behavior, even though many of these tumor were incompletely excised with a mean follow-up period of 7.7 years. ${ }^{7}$
In conclusion, hibernomas are benign tumors closely related to brown adipose tissue, which is rarely present in the human breast. Nevertheless, differential diagnosis must be done to rule out malignant neoplasias.

Conflicts to Interest

None to declare.

\section{References}

1 Cannon B, Nedergaard J. Brown adipose tissue: function and physiological significance. Physiol Rev 2004;84(01):277-359. Doi: 10.1152/physrev.00015.2003

2 Colville J, Feigin K, Tang L, Keating D, Cohen MA. Mammary hibernoma. Breast J 2006;12(06):563-565. Doi: 10.1111/j.15244741.2006.00346.x

3 Gardner-Thorpe D, Hirschowitz L, Maddox PR. Mammary hibernoma. Eur J Surg Oncol 2000;26(04):430. Doi: 10.1053/ejso.1999.0913

4 Martini N, Londero V, Machin P, et al. An unusual breast lesion: the ultrasonographic, mammographic, MRI and nuclear medicine findings of mammary hibernoma. Br J Radiol 2010;83(985):e1-e4. Doi: $10.1259 / \mathrm{bjr} / 17929543$

5 Padilla-Rodriguez AL. Pure hibernoma of the breast: insights about its origins. Ann Diagn Pathol 2012;16(04):288-291. Doi: 10.1016/j.anndiagpath.2011.01.004

6 Riley MP, Karamchandani DM. Mammary hibernoma: a rare entity. Arch Pathol Lab Med 2015;139(12):1565-1567. Doi: 10.5858/arpa.2014-0318-RS

7 Furlong MA, Fanburg-Smith JC, Miettinen M. The morphologic spectrum of hibernoma: a clinicopathologic study of 170 cases. Am J Surg Pathol 2001;25(06):809-814 